\title{
FLOOD RISK ASSESSMENT OF THE CITY OF CALGARY CONSIDERING FLOOD CONTROL BARRIER PERFORMANCE
}

\author{
G. Cocaign'1, 3a , T. Picton ${ }^{1,3}$, U. T Khan ${ }^{1}$, B. Beullac ${ }^{2}$, J. Sharma1 ${ }^{1}$, F. Mainguenaud ${ }^{1,2}$, L. Peyras ${ }^{2}$ \\ 1 York University - Lassonde School of Engineering, Toronto, Canada \\ 2 INRAE, Aix en Provence, France \\ ${ }^{3}$ Polytech Clermont-Ferrand, Clermont-Ferrand, France
}

\begin{abstract}
The 2013 flood in southern Alberta was one of the worst natural disasters in Canadian history. Heavy rainfall and a melting snowpack in the upstream Rocky Mountains resulted in higher-than-normal runoff in several Alberta watersheds. As the runoff reached downstream to the City of Calgary, the Bow and Elbow rivers overtopped its banks (including at several flood control barriers along the Rivers), causing several deaths, large-scale evacuations and an estimated $\$ 6$ billion in damages. Responding to this unprecedented flood event, the City of Calgary has implemented a Flood Resilience Plan to help reduce future flood risk. A key component of this plan is to analyze and improve existing flood control barriers (i.e., dike systems) along the rivers to improve performance and reduce the risk of riverine floods in the future. In this research, a probabilistic risk assessment process is developed and applied to assess the overall flood risk on existing dike systems along the Bow River in the City of Calgary. A steady-state hydraulic model of the Bow River is used to determine the water levels along the River for different return periods. The risk of failure of the dike systems (due to slope instability) is quantified using the Morgenstern-Price method and a Monte Carlo scheme that incorporates the uncertainty in the geotechnical properties of each barrier segment. The flood hazard is then quantified for each barrier segment considering each return period, risk of failure of the barrier, or overtopping due to high water levels. Following this, a multi-criteria approach that integrates the flood hazard with flood exposure and vulnerability is implemented to generate the overall flood risk map of the areas protected by the dike systems. The exposure (economic) and vulnerability (socio-demographic) are determined using geospatial data and an analytical hierarchical process. This process propagates the uncertainty from the data to the final probabilistic risk estimates. Results demonstrate the significance of including slope instability calculations when determining overall flood hazard. While dike systems may be designed to protect for a given return period (e.g. 100-year water level), there is a significant risk of failure of the barriers before reaching the designed water level. Additionally, certain protected areas face the compound hazard of overtopping and barrier failure - this hazard is not considered in existing analysis of the flood barriers along the Bow River. The overall risk assessment highlights those areas that have the highest combined risk and indicate the particular segments of the barriers that need design improvements to reach the City of Calgary's flood resilience goals.
\end{abstract}

\section{Introduction}

Every year, floods cause enormous damage all over the world. For instance, flooding caused by Hurricane Katrina in 2004 (ASCE, 2007) and Hurricane Xynthia in 2010 (Kolen et al., 2013), or flooding in Southern Alberta, Canada in 2013 (Pomeroy et al., 2016; Khan \& Valeo, 2016) had terrible consequences for human life and assets. Due to sea level rise and more frequent heavy precipitations projected throughout the $21^{\text {st }}$ century and beyond, the Intergovernmental Panel on Climate Change (IPCC) has predicted that coastal and riverine systems will increasingly experience adverse impacts such as these major floods (IPCC, 2014). IPCC (2014) also point out that if dike structures (or other flood control barriers) are used to mitigate flood hazards, they can only be effective if the structures are regularly operated and maintained. In fact, in case of breach on a dike system, the violence of the flood wave causes more damage than the natural gradual rise in water. In addition, this kind of failure is difficult to anticipate in terms of location and characteristics of the resulting floods, and thus, the management of flooded areas is much more difficult to organize than for floods which can be anticipated, e.g., areas without dikes or areas with dikes but without failure (Tourment et al., 2017).

To assure a long-term, acceptable performance of

\footnotetext{
a a Corresponding author: bruno.beullac@inrae.fr DOI 10.3311/FLOODRisk2020.14.3
} 
dike systems given the consequences of their potential failure, performance assessments and risk evaluations must be regularly carried out (Simm et al., 2012). To be effective and provide support to the development of optimal investment strategies, these actions must be integrated into flood risk management framework, including flood risk analysis and flood risk assessment (EC, 2007). Thus, the knowledge of the risk associated with the different parts of the dike system makes it possible to optimize its management to be able to propose measures to reduce the level of risk, or to maintain this level if it is acceptable (Tourment et al., 2014).

Based on the Source-Pathway-Receptor model, risk analysis of a dike systems estimates the overall level of risk associated with the system, according to a series of loading conditions, the performance of dikes and the vulnerability to flooding of assets in the protected areas (Samuels et al., 2009). This process has been formalized in the International Levee Handbook (ILH), which requires the identification and examination of all the components that determine the risk of flooding in the protected areas (CIRIA et al., 2013). Its main steps are: event probability estimation; analysis of dike system failure; inundation modelling; consequence estimation; estimating the level of risk; risk attribution; and, assessment of knowledge gaps.

Event probability estimation aims to estimate the probability and the intensity along the dike system (based on the flow discharge or water level within the river) of a range of the different possible flood loading conditions. The goal of inundation modelling is to identify and characterize inundation routes and the spatial coverage of the flood areas (including water depths, flow velocities, timing of inundation) in the protected area. These two steps of the risk analysis process, which are related to hydrology, river morphology and hydraulics, are classic engineering and research topics with updated methodologies and modelling tools (Knight et al., 2009; Bedient et al., 2018).

Dike system failure, which is defined as the inability to achieve a defined performance threshold (Allsop et al. 2007), occurs when a dike segment is no longer able to achieve, at the defined or assigned loading water level, its function of flood protection within the dike system (Simm et al., 2012). Different deterioration mechanisms may have an impact on dikes segments and lead to dike failure and possible breaching. These mechanisms have very different and complex forms and possible combinations, and a large variety of dike failure scenarios (sequence of deterioration mechanisms and associated damages on dike components) may be considered for a given dike segment (CIRIA et al., 2013). According to CIRIA et al. (2013), individual mechanisms of deterioration that affect dikes can be grouped into three main generic types: external erosions, internal erosions, and instabilities. Based on a combination of data, the performance of dike system failure can be analyzed through quantitative methods using expert judgment, index-based methods, or mathematical models (based on physical or empirical equations), and involves estimation of failure scenario probabilities for one or different loading events (Van der Meij et al., 2012).

Consequences of flooding may be direct (e.g. damaged buildings and/or contents) or indirect (e.g. loss of business earnings due to recovery time) (Messner et al., 2005; Penning-Rowsell et al., 2003). These consequences are estimated using a combination of hydraulic modelling results and the estimated vulnerability of the different assets located in the flood area (Smith et al., 1998; Parker et al., 1987). The latter is typically estimated using a function characterizing the damage based on the degree of flooding and is based on the hydraulic characteristics of the event. A natural flood area or a protected area can contain many different types of assets, and their vulnerability can be approached in different ways, for example: casualties or life loss (Jonkman et al., 2008), or social, economic and environmental consequences (Tapsell, 2008). Thus, multi-criteria approaches prove to be very relevant for consequence analysis (Meyer et al., 2009).

Risk attribution is based on the results of risk estimation, whose goal is to combine probabilities and potential consequences of the dike system failure, using the results of the previous steps of the process (Gouldby et al., 2009). It aims to attribute the residual flood risk in the protected floodplain to individual dike segments or to parts of the protected area, and thereby inform the prioritization of intervention to further reduce the risk. Since it is not possible to protect against all flood events, all dike systems leave a residual risk of flooding. Risk attribution is generally done for each dike segment for different inundation scenarios (e.g., return periods), and lead to their relative classification according to the risk attributable to each, as, for instance, in the MDSF2 UK model (Environment Agency, 2015). In this model, risk is attributed to dike segments by tracking the dike segments from which came the inundation water volume (for each place of the protected area), after the calculations were conducted. To simulate the multiple combinations of possible dike failures and associated inundation scenarios, these calculations include a Monte Carlo sampling procedure. An application of the MDSF2 UK model on Thames Estuary has been presented by Gouldby et al. (2008). Other methodologies exist, such as the Dutch government model (Van Alphen, 2015; Alberts et al., 2014), which estimates global inundation risk for protected areas related to dike lengths for which flood consequences are approximately the same.

Many uncertainties exist within each step of the risk analysis process because of the high complexity of dike systems and assets within the protected area, the incompleteness of data, and the limitations of the methods used. Progressive refinement of risk estimation and subsequent improvement of dike system management can be achieved by assessing existing knowledge gaps in order to better understand the impact of uncertainties within the risk analysis process. Recent research (e.g., Vuillet et al., 2016; Peyras et al., 2015; Gelder et al., 2008) has suggested different methods to deal with the uncertainty in the structural performance of dikes, e.g., subjective probabilities were used to characterise the uncertainty of input data, and Monte Carlo simulations were used to propagate the parameter uncertainty in dike failure scenarios.

The 2013 Southern Alberta floods were the worst flood event in the province's history, and one of the largest 
natural disasters in Canadian history (Pomeroy et al., 2016). Some of the several kilometres of embankment dikes that protect downtown area of the City of Calgary (the largest city in Alberta with a population of approximately 1.2 million) from Bow and Elbow rivers overtopped and were damaged at many locations (Golder Associates, 2014). The cost of this flood event, which killed four people, was evaluated at six billion Canadian dollars (The City of Calgary, 2018). After the 2013 flood event, the City of Calgary decided to start a process of reducing flood risk, and especially emphasized the need to acquire a powerful tool to assess dike systems performance and associated flood risk. In this context, this article describes the application of a risk analysis process to a dike system protecting a flood area within the City of Calgary from the Bow River floods. This case study, which integrates all the steps of the ILH risk analysis process (CIRIA et al., 2013) and is inspired by the UK Environment Agency approach (Environment Agency, 2015), propagates uncertainties from data to risk estimation. Each step of the risk analysis process is treated in a simplified way to demonstrate the overall process. Dike performance is studied through the sliding instability mechanism using Monte Carlo simulation to deal with uncertainties on geotechnical parameters, as well as overtopping (when the water level is higher than the dike level). Consequences in the flooded areas are evaluated through a socio-economic multi-criteria analysis, and flood risk is attributed to each segment of the dike system for a range of flood loading events.

\section{Method overview}

The method used in this paper follows the main steps presented below; the interaction of each step to produce the final flood risk attribution is presented in Figure 1. Details of the specific application for the City of Calgary are presented in Section 3.

1. Hydrological and hydraulic analyses:

a. Hydrological analysis where water stage, discharge and climatic data are used to determine river water discharge for a range of flood event frequencies (i.e. return periods), from normal to extreme events.

b. Hydraulic simulations of flood events, using results from Step 1a, topographic and bathymetric data, to determine the river flood water level along dike segments, for different flood event frequencies (including a quantification of uncertainties on water levels). Both steady-state and transient simulations were conducted.

2. Dike system structural analysis:

a. Characterization of dike system properties and identification of homogeneous dike segments: according to the nature and geometry of the structural components of the dike segments.

b. Identification of possible structural failure scenarios for each homogeneous dike segment using reliability methods.

c. Determination of probabilistic distributions of safety factors for each failure scenario, for each homogeneous dike segment (according to probabilistic distributions of geotechnical parameters and Monte Carlo simulations) for the different flood event frequencies.

d. Determination of fragility curves (probability of failure according to probability of flood loading conditions) for each dike segment, for each failure scenario, and for an aggregation of all failure scenarios.

3. Flood assessment and risk attribution:

a. Development of inundation maps, resulting from each dike segment structural failure (due to breaches) and from the normal running of the dike system (overtopping without dike failure), for the different flood event frequencies.

b. Multi-criteria analysis to define the vulnerability of assets in the protected area, to obtain a map for social and economic vulnerabilities.

c. Assessment of inundations consequences by crossing the inundation maps with vulnerability map for each flood event frequencies and for each dike segment for both the failure and non-failure scenarios.

d. Flood risk estimation and attribution to each segment of the dike system to improve decision making about dike management and asset management.

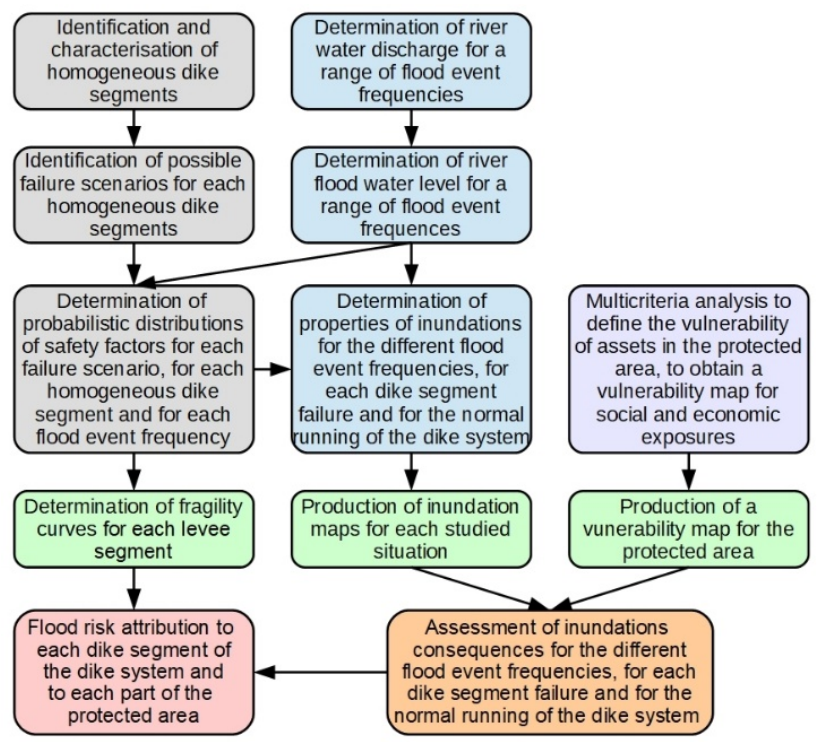

Figure 1. Overview of the method used to assess the overall flood risk for dike systems

\section{Application, results, and discussion of the method}

The proposed risk assessment described in the previous section was applied to the Bow River in Calgary, Canada. Data for each component of the analysis was collected and is described in detail below.

\section{Hydrology and hydraulics of the Bow River}

The Bow River originates in Bow Lake in the Rocky Mountains and flows in a south-easterly direction through the City of Calgary and to Hudson Bay. The Bow River has an average slope of $0.4 \%$ over its $645 \mathrm{~km}$ length, 
draining an area of approximately $25,123 \mathrm{~km}^{2}$ (Khan et al., 2018). Snowpack in the Rocky Mountains supplies the river along with rainfall and discharge from shallow groundwater. Flow peaks in June while low flows occur in the winter. The Bow River flows through the commercial centre (downtown) of the City of Calgary.

For this research, daily discharge data was collected from Environment Canada for the period from 1933 to 2015 from the Station 05BH004, which is located in central Calgary. The annual median discharge for this site is typically between 47 to $85 \mathrm{~m}^{3} / \mathrm{s}$, whereas the annual peak discharge is between 172 to approximately $1500 \mathrm{~m}^{3} / \mathrm{s}$ (which was observed during the 2013 floods). Frequency analysis was conducted on this data to determine the flood frequency (i.e. return period) for the River and this data is summarised in Table 1 below. This analysis suggests that the 2013 floods, which caused a large amount of damage, had a return period of approximately 75 to 80 years.

A calibrated HEC-RAS model provided by the City of Calgary was used for this analysis. The study area within downtown Calgary is illustrated in Figure 2 which highlights the different dike segments and cross-sections of the River in blue. Note that for this analysis, the dike systems on the north bank of the Bow River were analyzed (since these dikes are Earth dikes) and subject to failure during high discharge conditions. The detailed bathymetry data provided in the HEC-RAS model was used to estimate the water level in the River under different flow conditions. A $30 \mathrm{~m}$ resolution Digital Elevation Model provided by the York University Library was used to estimate flood depths in the protected areas.

Table 1: Summary of discharge values for the Bow River

\begin{tabular}{cc}
\hline $\begin{array}{c}\text { Flood frequency } \\
\text { (years) }\end{array}$ & $\begin{array}{c}\text { Discharge } \\
\left(\mathbf{m}^{\mathbf{3}} / \mathbf{s}\right)\end{array}$ \\
\hline 100 & 2235 \\
75 & 1742 \\
50 & 1140 \\
40 & 790 \\
25 & 595 \\
20 & 560 \\
10 & 473 \\
5 & 410 \\
2.33 & 340 \\
2 & 320 \\
\hline
\end{tabular}

An analysis of the flow regime (steady and unsteady conditions) noted a very small $(\sim 5 \%)$ variation in water levels for each flood frequency. In addition to this, previous research (Khan and Valeo, 2016) has suggested that the uncertainty in discharge measurements can be as high as $\pm 8 \%$ for this River under high flow conditions. This uncertainty value was included in all analysis to account for the worst case scenario for the flood risk assessment. The HEC RAS model was run in both steadystate conditions (where the values listed in Table 1 were used), and for unsteady conditions, where a synthetic hydrograph to construct the time series of the discharge were used. A triangular, 24-hour duration hydrograph was used, where the discharge increases from the baseflow to the peak in 8 hours and reduces back to the baseflow in the next 16 hours.

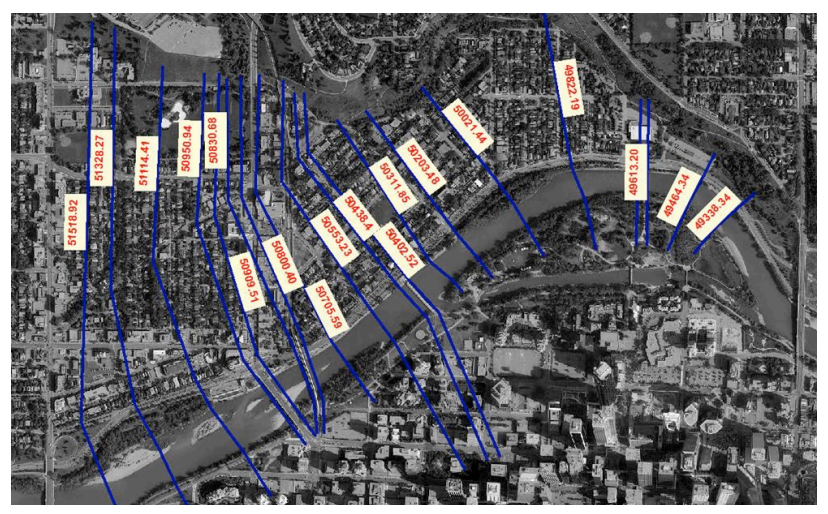

Figure 2: An overview of the HEC RAS model cross-sections with the City of Calgary.

An analysis of both steady-state and transient discharge conditions showed that the risk of inundation due to overtopping is low to non-existent for the majority of the flood frequencies considered, as expected, due to the construction of the dike system. However, under steadystate conditions, of the 16 cross-sections analyzed, 12 overtopped for the 100-year frequency, 10 for the 75 -year frequency, 6 for the 50-year frequency, 1 for the 25 -year frequency. For the transient conditions on the other hand, overtopping was observed for 14 of the cross-sections for the 100-year frequency, and 9 cross-sections for the 75year frequency, with no overtopping (and thus, no flooding based only on water level depths) for the other frequencies. A sample inundation map for the steady-state condition for is shown in Figure 3 for the 50-year frequency.

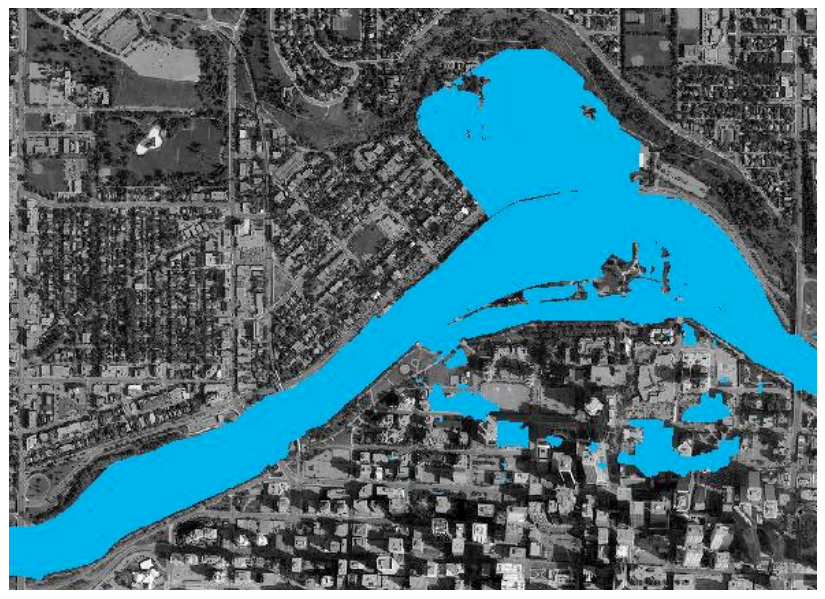

Figure 3: A sample flood map resulting from overtopping of the dike system in the Bow River for the 50-year frequency under steady-state conditions.

\section{Geotechnical study of dike system}

The aim of the present study was to develop a general model of risk analysis method and not to develop a tool for a full dike structural performance assessment. Thus, dikes 
of the City of Calgary being earth levees, it was decided to limit dike structural performance evaluation to the sliding instability mechanism (a well-known and easily calculable mechanism) using the GEO-SLOPE software with the Morgenstern-Price method.

Little to no field measurements of the dikes in Calgary were available for modelling the dike stability, other than the fact the dike systems are constructed out of compacted impervious clay, and the surrounding soil consisting largely of silt. Thus, for soil properties (friction angle, cohesion, and unit weight) a mean value and standard deviation for each parameter was selected, and a normal distribution assumed, based on DYSLI (1997). This was necessary for the application of the Monte Carlo analysis. For the dike itself, the friction angle had a mean value of $21^{\circ}$ and standard deviation of $2^{\circ}$, the cohesion had a mean value of $0 \mathrm{kPa}$ with a standard deviation of $2 \mathrm{kPa}$ (with a maximum value of $10 \mathrm{kPa}$ ), and a mean unit weight of $18 \mathrm{kN} / \mathrm{m}^{3}$ and standard deviation of $1 \mathrm{kN} / \mathrm{m}^{3}$. Similarly, the surrounding soil properties were specified as follows: a mean friction angle of $33^{\circ}$ and standard deviation of $4^{\circ}$, a mean cohesion of $0 \mathrm{kPa}$ with a standard deviation of 1 $\mathrm{kPa}$ (with a maximum value of $2 \mathrm{kPa}$ ), and a mean unit weight of $19 \mathrm{kN} / \mathrm{m}^{3}$ and standard deviation of $1 \mathrm{kN} / \mathrm{m}^{3}$.

Other parameters needed for the stability analysis included dike geometry (which was obtained from the cross-section data in the HEC RAS model) including the height, and angle at the base of the dike, and the water level (at a given frequency) as a ratio of the overall dike height (which was obtained from the results of the HEC RAS model).

A comparative analysis to study each parameter's influence on the factor of safety was performed. This is especially important since measured data for the dike properties were unavailable. This analysis demonstrated that when cohesion decreases, the factor of safety also decreases. Similarly, as the friction angle increases, the factor of safety also increases, and lastly, increasing the water level decreases the factor of safety. Overall, the analysis in GEO-SLOPE demonstrated that the magnitude of the friction angle has the largest effect on factor of safety, whereas the cohesion had the least effect.

Following this, slope stability analysis was performed for all cross-sections within the dike segments for both steady-state and transient discharge conditions, using the material properties listed above. The analyses were conducted for all water level frequencies listed in the previous section. The results from the analyses demonstrate flooding due to overtop-only and due to overtopping following slope stability failure. The condition where both overtopping and slope stability failure occur together were also investigated, but results showed that this did not affect the resultant flood maps.

Figure 4 shows a standard cross-sectional profile of a dike system along the Bow River based on the HEC RAS model, and imported into GEO-SLOPE. Similar models were developed for each cross-section highlighted in Figure 2 for the slope-stability analysis.

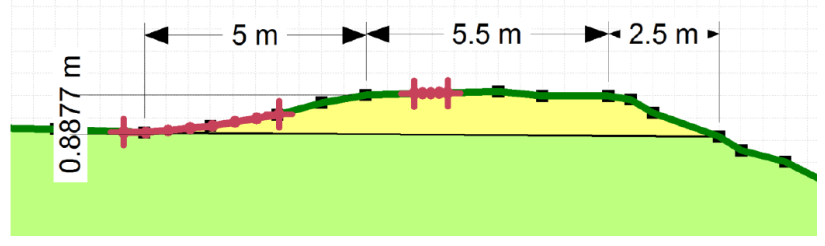

Figure 4: A cross-sectional profile of the dike system along the north bank of the Bow River in Calgary.

Results for the transient analyses were similar, but with a lower spatial extent of inundation within the protected areas. Overall, the probability of failure for the dike segments along the Bow River were low. Using steadystate analysis, the probability of failure ranged from $0.05 \%$ to $5 \%$, with similar results for the unsteady simulations, except for one cross-section where the probability of failure was $100 \%$ (for a 75 -year return period).

The Monte Carlo analysis was run for a total of 10,000 simulation each to determine the probability density function of the factor of safety. The results of the analysis showed that five of the cross-sections shown in Figure 2 never fail (where the failure is defined as a factor of safety below 1). However, for the remaining cross-sections, the probability of failure varied from cross-section to crosssection (a function of the geometry), and increased with the flood frequency (i.e., the water level), as expected.

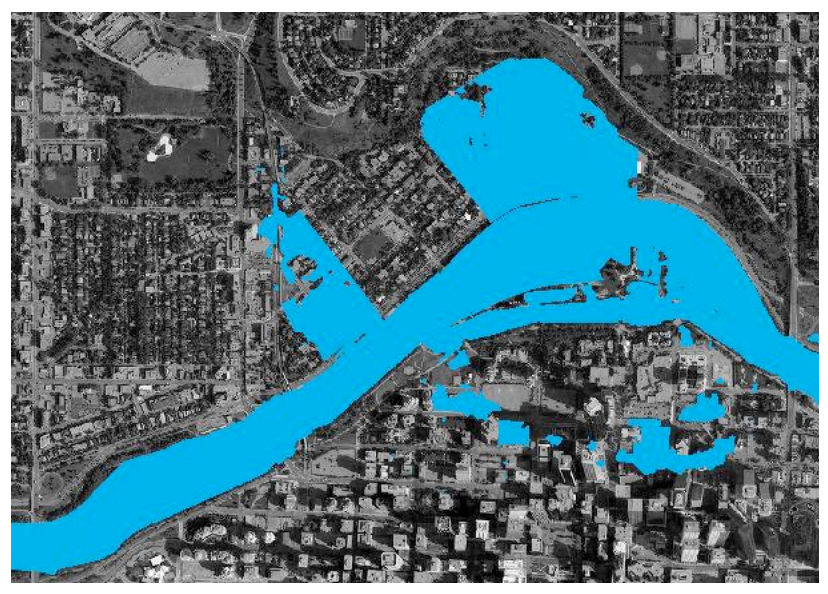

Figure 5: A flood map resulting from overtopping and failure of the dike system for the cross-section 50553.23 in the Bow River as in Figure 2 for the 50-year frequency under steadystate conditions.

\section{Flood risk assessment for the City of Calgary}

Following the hydrological and hydraulic analyses, and the geotechnical slope stability analysis, the risk of dike failure was integrated together, and combined with the consequences of the protected area to yield the final flood risk along the Bow River. The analysis of the consequences (including both social vulnerability and economic exposure) is described below and follows the procedure outlined in Rincón et al. (2018). 
Geospatial data for the City of Calgary was collected to determine the vulnerability of the protected areas both in terms of social vulnerability and economic exposure. For the social vulnerability, the age of the population (specifically the number of people above the age of 75 years, and the number of people below the age of 4 years), income level (specifically those people with a Low Income Level, defined as $50 \%$ of the Canadian median income), and the overall population density of the area. These indicators have been routinely used in flood risk assessment (Rincón et al. 2018) because they represent different components of social vulnerability. For example, low income people have less access to resources during a flood event (e.g., temporary housing) and thus have a higher vulnerability. This data was collected for the protected areas along the Bow River, and an analytical hierarchical process (AHP) was used to combine the data into one category using ArcGIS. The results of the analysis are shown in Figure 6, where the class "1" represents low social vulnerability and " 5 " represents high vulnerability. The majority of the protected area is in class " 3 " in the middle of the City of Calgary.

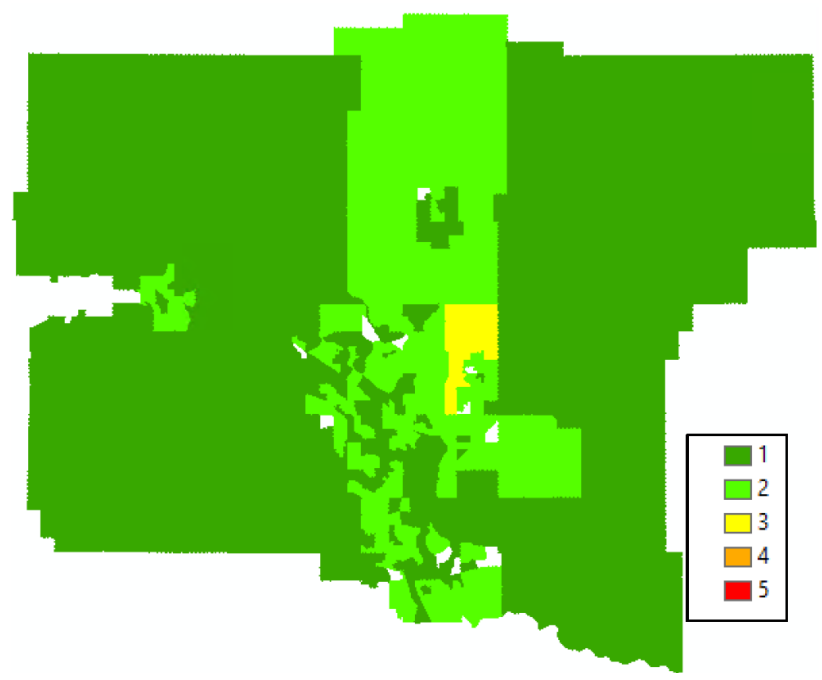

Figure 6: Results of the social vulnerability analysis for the City of Calgary using geospatial data and the AHP process.

Following this, a similar process was followed to establish the economic exposure of the protected areas. For this, the data used consisted of land-cover type for the City of Calgary as an indicator for overall economic value of different regions. Industrial and resource areas were assigned the highest (i.e., most important) economic value of " 5 ", followed by commercial (4), government, institutional and infrastructure (3), residential (2), and parks and recreational area (1). This categorisation follows the choices used in Rincón et al (2018). The resulting map showing the economic exposure for the City of Calgary can be seen in Figure 7.

Finally, the social and economic results were combined to develop an overall metrics of consequences for the study region. This was done by combining both datasets using the Spatial Overlay Tool in ArcGIS. For this research, we selected equal weighting for both the social and economic data $(50 \%$ each) to develop the final consequence data. This resulted in new consequence maps for the City of Calgary ranging between 1 and 5, with 1 being low consequence and 5 being high consequence. The number of cells within each map belonging to each category were then summed up to determine the overall consequence rating for the protected areas. This was overlaid with the flood maps generated from the previous sections (either through overtop-only or overtopping due to dike failure), resulting in flood risk maps; a sample is shown in Figure 8.

This data was then combined with the flood maps developed in the previous sections (either overtop-only or overtopping due to dike failure), for each flood frequency. The overall risk was defined as the product of the probability of failure, the probability of the flood frequency (the hazard, in this case) and the consequences. For each return period, these results were integrated from each cross-section along the dike sections to develop a risk attribution figure for the Bow River. A sample for the 50year return period risk is shown in Figure 9. Note that " 1 " refers to low risk and " 5 " refers to the highest risk. The area identified in blue colour is the area where overtopping (without failure of the dike occurs).

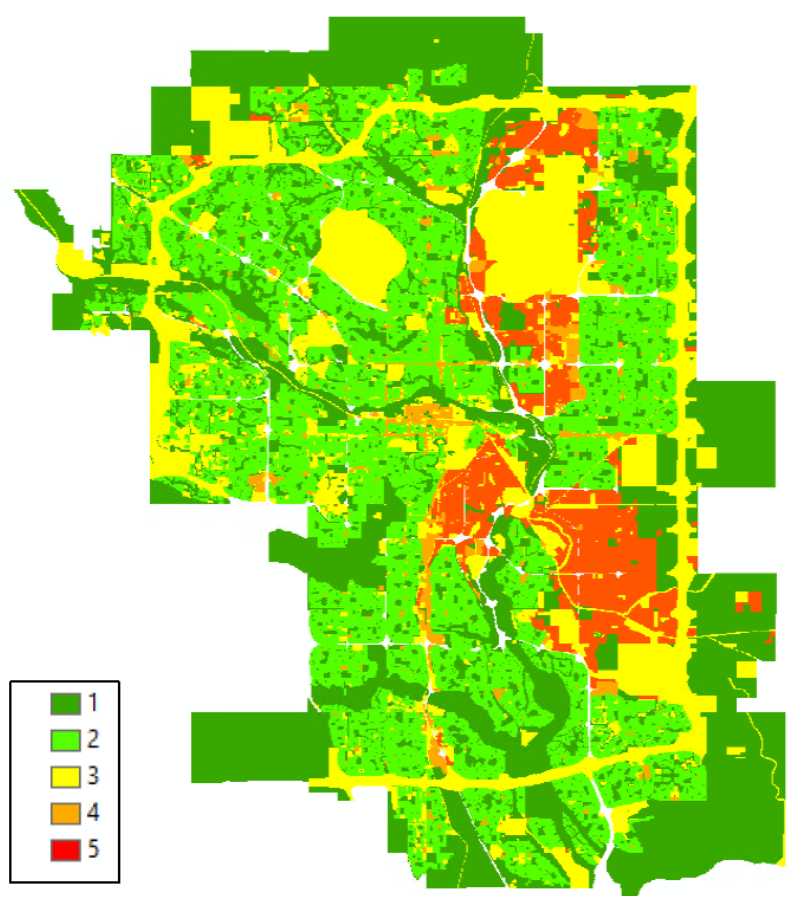

Figure 7: Results of the economic vulnerability analysis for the City of Calgary using land-cover data as an indicator for economic value. 


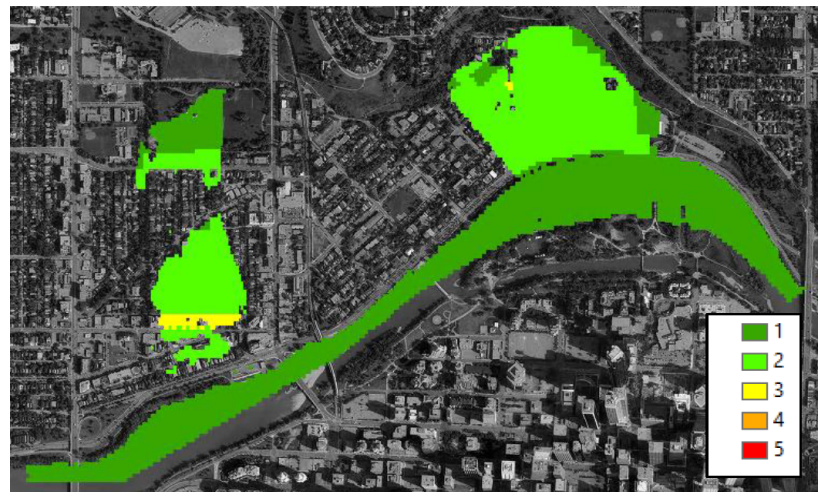

Figure 8: Final flood risk assessment for a dike segment that combines the flood due to dike failure, for a 35-year frequency, and social and economic consequences.

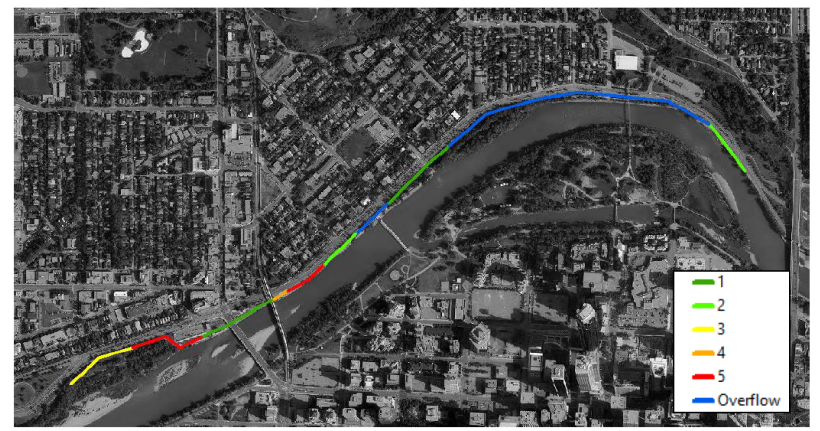

Figure 9: Final flood risk attribution along the Bow River for all cross-sections along the dike segments for the 100-year flood frequency.

\section{Conclusion}

The 2013 floods in Calgary caused widespread damage and several deaths. To mitigate future flood risk, the City of Calgary has implement a Flood Resilience Plan. A key component of this plan is to analyze and improve existing flood control barriers (i.e., dike systems) along the Bow River to improve performance and reduce the risk of riverine floods in the future. In this research a probabilistic risk assessment process is developed and applied to assess the overall flood risk on existing dike systems which accounts for the risk due to overtopping of the dikes, and overtopping along with dike failure. Overtopping was modelled through a hydraulic model for several return periods, whereas dike failure was modelled through slope stability analysis. The overall risk quantified both the social vulnerability and economic exposure through geospatial analysis.

Overall, the results of this research demonstrate the significance of including slope instability calculations when determining overall flood hazard and flood risk. While dike systems may be designed to protect for a given return period (e.g., 100-year water level), there is a risk of failure of the barriers before reaching the designed water level due to dike slope stability issues. Thus, flood risk mitigation strategies should include the risk of failure of dike systems as part of the overall flood risk. Additionally, this research shows that certain protected areas face the compound hazard of overtopping and barrier failure - this hazard is not considered in existing analysis of the flood barriers along the Bow River in Calgary. The overall risk assessment highlights those areas that have the highest combined risk and indicate the particular segments of the barriers that need design improvements to reach Calgary's flood resilience goals.

Note that there are several assumptions and limitations of the proposed approach used in this research. Dike failures are much more complex in reality than the simple mechanism used here; in particular external and internal erosion of the dike, along with breaches of the dike system contribute to the overall risk of failure. Also, more accurate geotechnical data, collected from field surveys of the dike system, would be improve the reliability of the slope stability analysis used for this research.

This research produced a risk attribution for the Bow River along the length of the dike system for each return period studied. However, future work should focus on integrating the return periods with the risk of failure to produce a single risk of failure that combined all return periods together. Similarly, future work should also include the use of region-specific depth-damage curves to estimate the economic vulnerability of the protected region, rather than relying on coarse-resolution economic indicators. Lastly, the impact of future climate change on flood risk in this region should also be quantified using climate change projections in a hydrological model to drive the hydraulic model of the Bow River.

\section{Perspectives}

Further research opportunities are intended about spatialized probabilistic study of flood risk assessment in areas protected by dikes. We will present the objectives followed by the scientific issues and an overview of the identified research opportunities.

In order to strengthen the already existent methodologies, we defined precise objectives to tackle. First, we aim to improve probabilistic flood risk assessment, taking into account the flood risk probabilistic methods that have been introduced since 10 years. Second, we would like to enable its use to different kind of levee protected areas in river environment. As much as possible, we would like to include different country specificities into the method. Finally, given the present-day climate changeoriented area, we also wish to include climate change related parameters in flood risk assessment.

To meet these different goals, we would like to expose some of the scientific issues that will be tackled on. Firstly, developing a spatial and temporal probabilistic flood risk analysis method presents its own set of challenge. Combining spatial and temporal aspects adds to the overall complexity of the model. Moreover, the timestep considered would be non-homogeneous as it varies depending on temporal and spatial frame studied. Developing such a method would induce the following issues.

Simulating a large number of potential dike break scenarios needs extensive data acquisition. This step is invariably flawed with several uncertainties among which 
variability and imprecisions have to be processed. A key point for this research issue is to remain operationalfriendly by limiting the computation time. Furthermore, some failure mode scenarios may require expert judgment assessment which include various biases that will need to be corrected.

Then, assessing levee failure probabilities by spatialized methods represents a challenge due to the various interactions to consider. This GIS-based approach should ease the reading of levee failure probabilities. However, the computing time remains one of the main issue due to the amount of data to be handled.

Lastly, estimate the hydraulic loads applied on levees through the use of probabilistic assessment methods is presented as an issue as it varies frequently and significantly with the level of the river and during the levee service life. A high frequency rate of loading and unloading of the levee may weaken the structures involved throughout the river, especially for earth levees as in Calgary.

An overview of research opportunities defines flood risk by three temporal phases centered on a hazard occurrence: before, during and after a hazard occurrence. Anchored in the "before" phase, we aim to pursue an international take on flood risk assessment. Existing probabilistic methods have been improved to meet each country needs, specificities and are linked to a given environment. By taking on each expertise of methods for various problems, we will try to implement new probabilistic approaches to build up complimentary methodologies to improve probabilistic flood risk assessment.

\section{References}

1. Alberts F., Most H., van der Hoogbergen F. (2014) Deltaprogramma Veiligheid, Synthesedocument Veiligheid, (in Dutch), Ministerie van Infrastructuur en Milieu, The Netherlands, https://docplayer.nl/68886965-Synthesedocumentveiligheid.html

2. Allsop W., Kortenhaus A. \& Morris M., (2007). FLOODsite - Failure Mechanisms for Flood Defence Structures, FLOODsite. Available at: http://www.floodsite.net/html/partner_area/project_d ocs/T04_06_01_failure_mechanisms_D4_1_v1_1_p 01.pdf.

3. ASCE (2007) The New Orleans hurricane protection system: what went wrong and why, ASCE Hurricane Katrina External Review Panel, Reston VA, USA (ISBN: 978-0-78440-893-3)

4. Bedient P.B., Huber W.C., Vieux B.E. (2018) Hydrology and floodplain analysis, 6th edition, Pearson, London (ISBN: 978-0134751979)

5. CIRIA, MEDDE (Ministère de l'Ecologie du Développement durable et de l'Energie), USACE (US Army Corps of Engineers). (2013). The International Levee Handbook. CIRIA, London (ISBN: 978-086017-734-0).

6. DYSLI M. (1997). Cycle postgrade: Geologie Appliquée à l'Ingénierie et à l'Environnement.

\section{Retrieved}

from

https://lms.epfl.ch/files/content/sites/lms/files/shared/ Publications/Soil\%20and\%20Rock/Mecanique_des_ sols_GAIE.pdf

7. EC (2007), Directive 2007/60/EC of the European Parliament and of the Council, published in the Official Journal of the European Union, L 288/27, 6 November 2007.

8. Environment Agency (2015). Modelling decision support framework (MDSF2) for flood risk management strategies: oversight report. Report SC120062/R1. ISBN 978-1-84911-356-4, $\mathrm{SC} 120062 / \mathrm{R}$

9. van Gelder P.H.A.J.M., Buijs F., Ter W., Kanning W., Mai C., Rajabalinejad M., De Boer E., Gupta S., Shams R., van Erp N., Gouldby B., Humphrey G., Sayers P., Wills M., Kortenhaus A., Lambrecht H-J. (2008). Reliability analysis of flood defence structures and systems in Europe. 10.1201/9780203883020.ch69.

10. Golder Associates. (2014). Bow River and Elbow River - Basin-Wide Hydrology Assessment and 2013 Flood documentation. Report Number: 13-13260054-2000. 79

p.

http://www.calgary.ca/_layouts/cocis/DirectDownloa d.aspx?target $=$ http $\% 3 \mathrm{a} \% 2 \mathrm{f} \% 2 \mathrm{fwww}$.calgary.ca $\% 2 \mathrm{fU}$ EP\%2fWater\%2fDocuments\%2fWater-

Documents\%2fFlood-Info-

Documents\%2fRiver\%2520Hydrology\%25202014.p df \&noredirect $=1 \& \mathrm{sf}=1$

11. Gouldby B P, Klijn F, Samuels PG, Sayers PB \& Schanze J (2009). Language of Risk - Discussion Document, FLOODsite Report T32-04-01 (Second Edition), www.floodsite.net

12. Gouldby, B P, Sayers, P, Mulet-Marti, J, Hassan, M and Benwell, D (2008) "A methodology for regional scale flood risk assessment". In: Proceedings of the ICE - Water Management, vol 161, 3, Institute of Civil Engineers, UK

13. IPCC (2014). Climate Change 2014: Impacts, Adaptation, and Vulnerability. Part A: Global and Sectoral Aspects. Contribution of Working Group II to the Fifth Assessment Report of the Intergovernmental Panel on Climate Change [Field, C.B., V.R. Barros, D.J. Dokken, K.J. Mach, M.D. Mastrandrea, T.E. Bilir, M. Chatterjee, K.L. Ebi, Y.O. Estrada, R.C. Genova, B. Girma, E.S. Kissel, A.N. Levy, S. MacCracken, P.R. Mastrandrea, and L.L.White (eds.)]. Cambridge University Press, Cambridge, United Kingdom and New York, NY, USA, 1132 pp.

14. Jonkman, S N, Vrijling, J K and Vrouwenvelder, A C W M (2008)."Methods for the estimation of loss of life due to floods: A literature review and a proposal for a new method" Natural Hazards, 46, 3, Springer Link, UK, pp 355-389

15. Khan, U. T., and Valeo, C. (2016). Short-Term Peak Flow Rate Prediction and Flood Risk Assessment Using Fuzzy Linear Regression. Journal of Environmental Informatics, 28(2): 71-89, DOI: 10.3808/jei.201600345 
16. Khan, U. T., He, J., and Valeo, C. (2018). River flood prediction using fuzzy neural networks: an investigation on automated network architecture. Water Science and Technology, 2017(1), 238-247. DOI: $10.2166 /$ wst.2018.107

17. Knight, D W, McGahey, C, Lamb, R, and Samuels, P (2009) Practical channel hydraulics: roughness, conveyance and afflux, CRC Press, Taylor \& Francis, UK (ISBN: 978-0-41554-974-5)

18. Kolen, B., Slomp, R. and Jonkman, S.N. (2013), The impacts of storm Xynthia February 27-28, 2010 in France: lessons for flood risk management. Journal of Flood Risk Management, 6: 261-278. doi: 10.1111/jfr3.12011.

19. Messner, F and Meyer, V (2005) "Part 4 Vulnerability and flood damages. Flood damage, vulnerability and risk perception. Challenges for flood damage research". In: Flood risk management. Hazards, vulnerability and mitigation measures, J Schanze, E Zemen and J Marsalek (eds), NATO Science Series, IV earth and environmental sciences, vol 67, Ostrov, Czech Republic, 2004 (ISBN: 978-1-40204-597-4)

20. Meyer, V., Scheuer, S. \& Haase, D. Nat Hazards (2009) 48: 17. https://doi.org/10.1007/s11069-0089244-4

21. Parker, D J, Green, C H and Thompson, P M (1987) Urban flood protection benefits: a project appraisal guide (The Red Manual), Avebury Technical, UK (ISBN: 978-0-29139-707-2)

22. Penning-Rowsell, E, Johnson, C, Tunstall, S, Tapsell, S, Morris, J, Chatterton, J, Coker, A and Green, C (2003) The benefits of flood and coastal defence: techniques and data for 2003, Flood Hazard Research Centre, Middlesex University (out of print)

23. Peyras L., Tourment R., Vuillet M., Beullac B., Delaunay C., Bambara G. (2015). Development of an expert-led GIS-based approach for assessing the performance of river levees: the Digsure method and tool. Journal of Flood Risk Management. DOI $10.1111 / \mathrm{jfr} 3.12178$.

24. Pomeroy, J.W., Stewart, R.E., Whitfield, P.H. (2016). The 2013 flood event in the South Saskatchewan and Elk River basins: Causes, assessment and damages, Canadian Water Resources Journal / Revue canadienne des ressources hydriques, 41:1-2, 105117, DOI: 10.1080/07011784.2015.1089190

25. Rincón, D., Khan, U. T., \& Armenakis, C. (2018). Flood Risk Mapping Using GIS and Multi-Criteria Analysis: A Greater Toronto Area Case Study. Geosciences, 8(8), 275, DOI : 10.3390/geosciences 8080275

26. Samuels, P.G., Morris, M.W., Sayers, P., Creutin, JD., Kortenhaus, A., Klijn, F., Mosselman, E., Van OS, A., Schanze, J. (2009). Advances in flood risk management from the FLOODsite project. In: Flood Risk Management: Research and Practice - Samuels et al. (eds) 2009 Taylors \& Francis Group, London, ISBN 978-0-415-48507-4. pp.433-443

27. Simm, J.D., Wallis, M., Smith, P., Deniaud, Y., Tourment, R., Veylon, G., Durand, E., McVicker, J., Hersh-Burdick, R., Glerum, J. (2012). The significance of failure modes in the design and management of levees - a perspective from the International Levee Handbook team. In FloodRisk 2012 - 2nd European Conference on FloodriskManagement. Rotterdam, Netherlands, 20th-22nd November 2012. Klijn \& Schweckendiek (eds) (C) 2013 Taylor \& Francis Group, London, ISBN 978-0-415-62144-1.

28. Smith, K and Ward, R (1998) Floods: physical processes and human impacts, Wiley-Blackwell, Chichester (ISBN: 978-0-47195-248-0)

29. Tapsell, S (2008) Socio-economic and ecological evaluation and modelling methodologies, Floodsite Report T10_07_13, FLOODsite Consortium.

30. Tourment, R., Beullac, B., Poulain, D. (2017). "Management and safety of flood defense systems". In : Freddy Vinet (coord.), Floods Volume 2 - Risk Management. ISTE Press - Elsevier, 2017, p. 31-44.

31. Tourment R., Wallis M., Beullac B., Kortenhaus A., Schaaf D., Schelfhout H. (2014). The risk analysis of levee systems. 3rd IAHR Europe Congress, Book of Proceedings, 2014, Porto - Portugal.

32. van Alphen, J. (2015). The Delta programme and updated flood risk management policies in the Netherlands. Journal of Flood Risk Management, 9: 310-319. doi: 10.1111/jfr3.12183.

33. van der Meij, R., van den Ham, G.A., Morris, M., Lhomme, J., Tourment, R., Maurel, P. (2012) Combining Different Data Sources for Assessment of Urban Flood Defences. In 2nd European Conference on Floodrisk Management. Rotterdam Netherlands, 20th-22nd November 2012. Klijn \& Schweckendiek (eds) (C) 2013 Taylor \& Francis Group, London, ISBN 978-0-415-62144-1.

34. Vuillet, M., Peyras, L., Carvajal, C., Diab, Y., (2016). Developing a Probabilistic Multicriteria Method for River Levee Performance Evaluation in Support of Diagnostic Analysis. Journal of Infrastructure Systems - ASCE. Volume 22 Issue 3 - September 2016. DOI: 10.1061/(ASCE)IS.1943-555X .0000283 